\title{
Socio-economic Consequences and Prospective Opportunities of the International Labour Migration as a Process of the Global Labour Market Development
}

\author{
Submitted 12/08/19, $1^{\text {st }}$ revision 18/09/19, $2^{\text {nd }}$ revision $24 / 10 / 19$, accepted $24 / 11 / 19$
}

\author{
Petrovskaya N.E. ${ }^{1}$, Kutsegreeva L.V. ${ }^{2}$, Maksaev A.A. ${ }^{3}$, Raevich I.A. ${ }^{4}$
}

\begin{abstract}
:
Purpose: The aim is to study the causes, processes and economic consequences of remittances carried out during international labour migrations in the global labour market.

Design/Methodology/Approach: The comprehensive analysis of remittances of migrants based on official data of the World Bank is carried out in this article. The systematic approach and logical research methods were used. The paper analyzes data on the remittances dynamics in the XXI century, shows the largest countries of senders and recipients of migrant workers remittances. Authors studied corridors of cash flows, the cost of transfers depending on the region of departure and the main transfer organizations.

Findings: Remittances from migrant workers is the significant amount of aid, especially for low-and middle-income countries, and it is the largest source of external financing for them. The economies of the number of countries are highly dependent on these transfers. According to experts, remittances of migrants are many times higher than the volume of the official development assistance to these countries, as well as remittances of migrants surpass the volume of the foreign direct investment. And according to forecasts, the volume of remittances will only grow.

Practical implications: The practical significance of the study is to substantiate and highlight the most important methodological and theoretical economic consequences of remittances of international migration flows.

Originality/value: The theoretical and applied value of the study is to substantiate the prospect area with better mechanisms for the implementation, accounting and stimulation of remittances by international labour migrants.
\end{abstract}

Keywords: Migration motives, remittances, migrant workers, the international migration.

JEL Code: F01, F24.

Paper Type: Commentary note: Migration.

\footnotetext{
${ }^{1}$ Senior Research Fellow, Institute for U.S. and Canadian Studies, Russian Academy of Science, Moscow, vitern@mail.ru

${ }^{2}$ Associate Professor of the Finance and Credit Department, Russian Economy University named after G. V. Plekhanov, dubinina@ mail.ru

${ }^{3}$ Associate Professor of the Management and Trade Deal Department, Krasnodar

Cooperative Institute, Krasnodar, maksaev@mail.ru

${ }^{4}$ Post-graduate of the Organization Management Department, University «Sinergija», Moscow, raevich@mail.ru
} 


\section{Introduction}

Since the beginning of the XXI century, the number of migrants in the world has increased by almost 70 million people and amounted to more than 247 million people or $3.4 \%$ of the world's population. The motives of the migration, the choice of the destination country differ significantly not only in the countries of origin of migrants, but also depend on individual, family preferences, opportunities in a particular period of time. The dynamics of migration flows depends, among other things, on the policies of the host countries (Petrovskaya, 2019). The main recipient countries of migrants are the United States, Saudi Arabia, Germany, Russia, UAE, United Kingdom, France, Canada, Spain and Australia. In the current decade, the growth of the migration dynamics actualizes the task of studying the structure of migrants, their position in the labour market, the participation in the life of the host society, as well as the importance of remittances of migrants to their historical homeland (Petrovskaya, 2019).

\section{Materials and Methods}

Reprospective studies of remittances of migrant workers is not great. In 1993, Western Union created Dinero en Minutos (Money in Minutes), a money transfer service from the United States to Mexico. Statistics on migrant remittances appeared about 15 years ago thanks to the work of the World Bank, the International Monetary Fund and the work of central banks. The World Bank has established the Global Knowledge Partnership on Migration and Development (KNOMAD), which regularly publishes reports on the migration and development that highlight the topic of remittances, including the Handbook: "Migration and Remittances Factbook".

Since 2007, The International Fund for Agricultural Development (IFAD), in cooperation with the World Bank, the UN Department of Economic and Social Affairs, the Inter-American Development Bank, the African Development Bank, has held The Global Forum on Remittances, Investment and Development (GFRID). It highlights current issues, trends, opportunities related to remittances and their role for the economies of donor and recipient countries. According to the results of the forum, reports are published. In 2018, the RemitScope Web platform (RemitScope, 2019) was launched. It presents data and the analysis of the remittance market in 50 countries mainly in the Asia-Pacific region, in the future it is planned to include data on other regions of the world.

\section{Results}

According to the latest report of the Global Knowledge Partnership on Migration and Development (KNOMAD) of the World Bank, the annual volume of officially registered remittances in 2018 amounted to 689 billion dollars, \$ 529 billion of these remittances were sent to low-and middle-income countries. Figure 1 presents the remittances dynamics in the XXI century. According to the World Bank, since the 
beginning of this century, remittances have increased more than 5 times, while it have increased 7 times in low-and middle-income countries. According to forecasts, in period between 2015 and 2030, migrants will send more than 8.5 trillion dollars to origin countries (IFAD, 2019).

Figure 1. The dynamics of remittances in the XXI century, billions of dollars (Compiled by the authors according to Remittance Inflow, 2019)

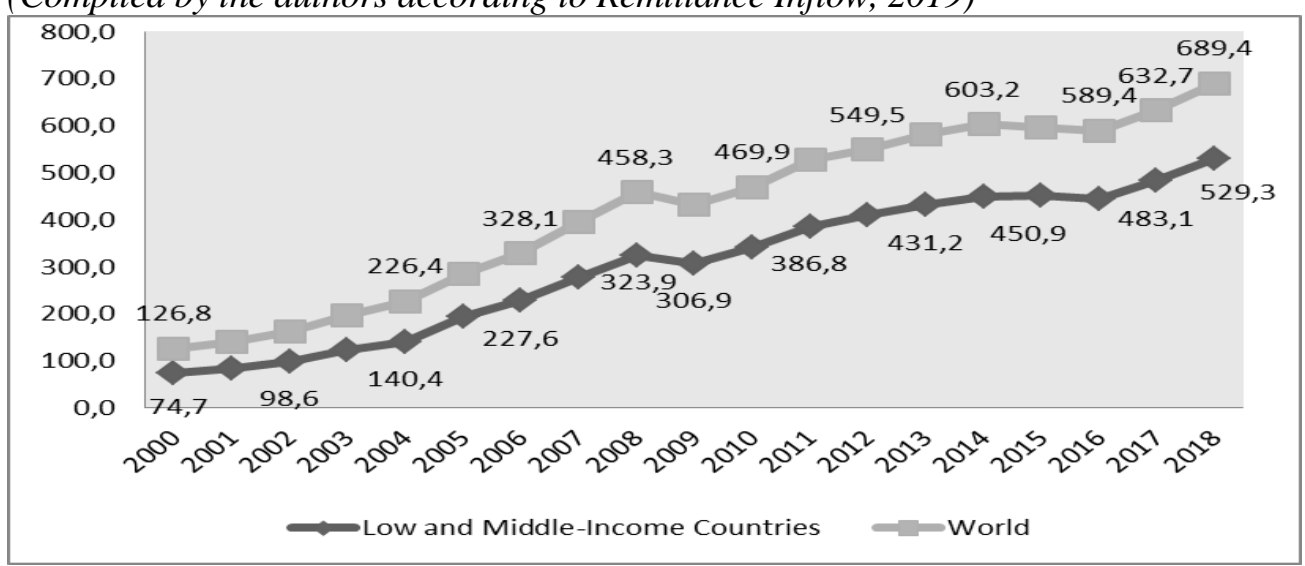

Such an amount of aid received by developing countries is almost three times higher the amount of the official development assistance to these countries, and also exceeds the amount of the foreign direct investment (Migration and Remittances Factbook, 2016; Rupeika-Apoga et al., 2019).

Figure 2 presents the 20 major remittance recipient countries which received $\$ 457$ billion in 2018 .

Figure 2. The largest recipient countries of migrant remittances in absolute terms, billions of dollars, 2018 data (Compiled by the authors according to Remittance Inflow, 2019)

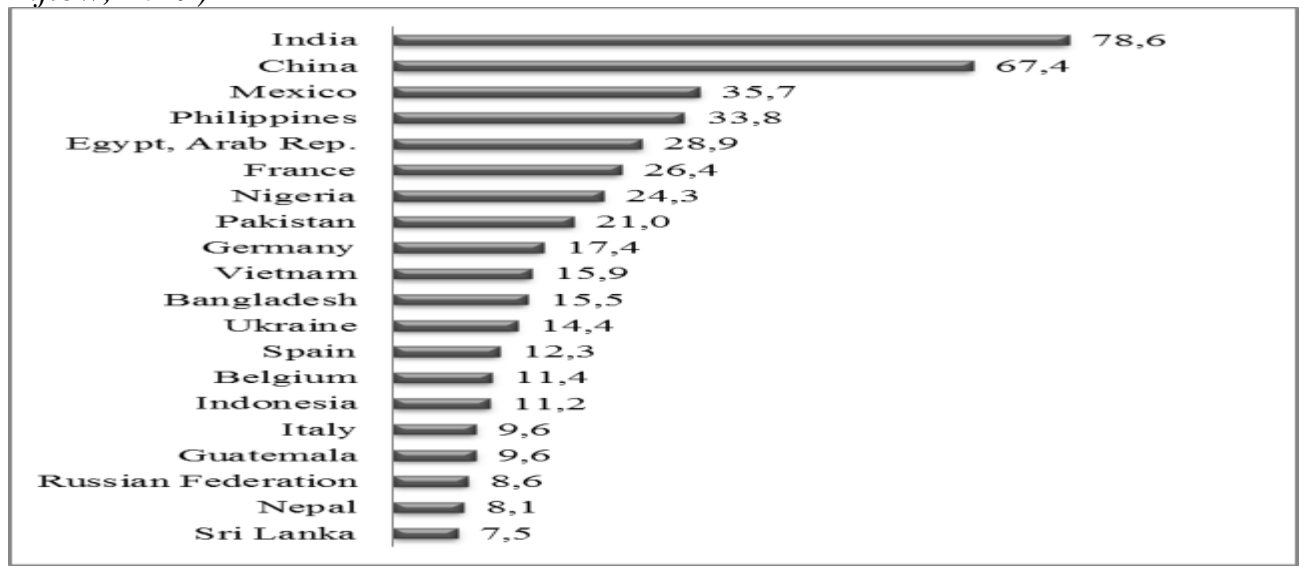


Economies of a number of countries are extremely dependent on these transfers: in the Kingdom of Tonga they account for 35\% of GDP, in Tajikistan they account for 31\%, in Kyrgyzstan they account for 34\%, in the Republic of Haiti they account for $31 \%$, in Nepal they account for 28\%, in El Salvador they account for $21 \%$ (Remittance Flow, 2019). Upper-income countries are the main sources of remittances. Remittances from migrants living in the United States is the significant portion of the total remittances to their historical homeland. In the second place is the UAE, followed by Saudi Arabia, the United Kingdom, Germany, Canada and others. More detailed data are presented in Figure 3.

Figure 3. The largest donar countries of remittances of migrants in absolute terms, billion dollars, 2017 data (Compiled by the authors according to Remittance Inflow, 2019)

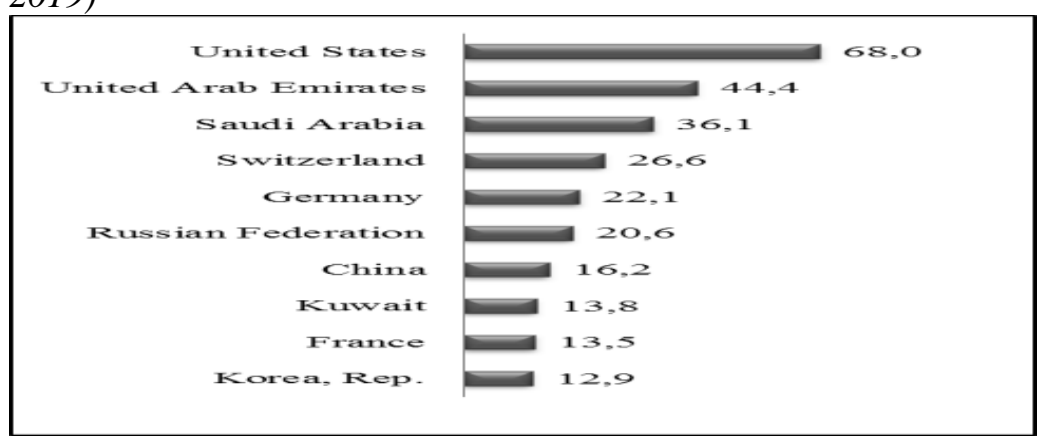

A large share of remittances of labour migrants from the United States is sent to Mexico, China, India, the Philippines, Guatemala and Vietnam. From Saudi Arabia, migrants send earned money to India, Egypt, Pakistan, Indonesia and Bangladesh, etc. From Russia, money transfers of migrant workers are sent to Ukraine, Uzbekistan, Kyrgyzstan, Tajikistan, Georgia and Armenia.

The largest remittance corridors are: USA-Mexico, USA-China, Hong Kong-China, UAE-India, USA-India (Migration and Remittances Factbook, 2016). Migrant remittances affect the life standard of millions of households, countries and even regions in general. According to the UN, half of the financial flows go to rural areas, where up to $75 \%$ of the world's poorest population is concentrated. The ability to send money home to support families is one of the key motivations for the labour migration. Remittances are an economic lifeline for many low-and middle-income families. It is interesting, the peak of remittances gets on the eve of mother's Day (May 12), as well as in December, in connection with the Christmas holidays.

June 16 was declared by the UN General Assembly as the International Day of Remittances in 2018. According to UN General Secretary Antonio Guterres, "family remittances have a direct impact on the lives of 1 billion people - that is, one in seven people on the Earth" (UN, 2018). More than 200 million migrants contribute to improving lives of 800 million members of their families, especially children. Most 
migrants send \$200-300 dollars per a month. Their remittances can account for up to $60 \%$ of the household income. The received money helps to get rid of extreme poverty, gain access to better health care, provide food for the family, educate children, create social capital, increase purchasing power and influence other areas. Thus, remittances of migrant workers become a significant factor in the development of the economy of their country of origin.

The cost of money transfers varies considerably. As in 2018, the average cost of sending a money transfer in the world was 6.9\% (Global Forum, 2018). The highest cost is in Sub-Saharan Africa and Pacific island states. For them, the cost of sending \$ 200 can be up to 19-20\% (Migration and Remittances Factbook, 2016). The average cost of sending money from Russia is the lowest cost among the G20 countries and it is $1.91 \%$. The money transfer below the global cost is also in a number of G20 countries such as the Republic of Korea (4.92\%), the United States (5.66\%), Saudi Arabia (5.18), Italy (6.16\%), France (6.64\%), Canada (6.79\%) (Remittance Prices Worldwide, 2019). The most expensive transfer channel according to the World Bank for the 2-nd quarter of 2019 are banks (10.49\%), post offices take the second place (8.81\%), the more budget way is MTO (Money Transfer Operator) (6.03\%), and the most expensive ways are transfers through mobile operators $(3.28 \%)$.

According to the World Bank, the main organizations that carry out money transfers from the United States are banks such as Citibank, Remitmoney, Wells Fargo, as well as MTO such as: Money Gram, Remintly, RIA, Transfast, Viamericas, Western Union, Xoom. In UAE banks: Direct Remit, Kotak Click2Remit, RemitMoney and MTO: Al Farad Exchange, Al Ansari, GCC Exchange, MoneyGram, Wall St Exchange, Western Union. In Saudi Arabia, banks: Al-Rajhi Bank, Enjaz Bank and MTO: TeleMoney, Xpress Money, MoneyGram, Western Union, SAMBA. In Germany, MTO: Azimo, TransferWise, MoneyGram, Western Union, and post office: Postbank. In Russia, MTO such as: Blizko, Contact, Money Gram, Unistream, Western Union, Zolotaya Korona (Golden Crown) (Remittance prices worldwide, 2019). Thanks to the digitalization, the number of money transfer agents is growing. Today, there are more than 1 million points for reception and dispatch of money in the Asia-Pacific region. Technological innovations could fundamentally transform the remittance market in the next decade.

Despite revolutionary changes in techniques, cash accounts for $90 \%$ of all remittances. According to experts they will dominate in the nearest future. Experts note «as customers become more sophisticated, the demand for real time, and more accessible and convenient services is likely to increase. Accordingly, the adoption of digital money is likely to increase, depending on factors such as costs» (Global Forum, 2018). In 2018, an important intergovernmental document was adopted. It was the Global Compact for Safe, Regular and Orderly Migration (GCM). The document contains goals that cover all the aspects of the international migration. One of the goals is directly related to money transfers: improving the speed and reliability and reducing 
the cost of remittances and promoting the financial integration of migrants and the pensions (Goal 20, UN General Assembly, 2018; Cristea and Thalassinos, 2016).

To achieve this goal, as well as to achieve one of the indicators of the Sustainable Development Goals, by 2030 countries plan to develop a "road map" in order to reduce tariffs on migrant remittances to below $3 \%$ and eliminate remittance channels with tariffs exceeding $5 \%$.

In addition, it is planned to apply tax benefits and incentives to remittances, promote access for various service providers to the market, and encourage the private sector to expand the range of services related to remittances. Innovations, including mobile techniques, the digitalization, blockchain, electronic banking, will continue to contribute to increasing the volume of transfers and increasing the availability of remittances for groups of the population, poorly covered by services, including those living in rural areas, women, persons with disabilities, persons with low education (UN General Assembly, 2018). Countries joined the GCM will encourage remittance senders to invest in the development and entrepreneurship in their countries of origin through counter-subsidy mechanisms, municipal bonds and partnerships with fellow countrymen, in order to spread the positive effects of remittances beyond individual households (UN General Assembly, 2018).

Remittances can be an engine of the development. About $75 \%$ of remittances are used to cover household running costs, and about $25 \%$ are saved or invested. It is important to offer reliable and understandable investment tools to the recipients of money transfers. In this regard, one of the most important tasks is to improve the financial and investment literacy of the population. It must be admitted that migrants send no more than $15 \%$ of their income, the rest of money they earn remains in the host country. Remittances are transforming the economic role of women, both in sending and receiving countries, affecting the financial independence and increasing the employment opportunities. As a rule, women send the higher share of their income despite the fact that they usually earn less than men (the gender gap in the world is about 20\%). As a part of the implementation of the GCM, countries encourage the active participation of women in the economy. It is planned to provide women migrants with opportunities to improve financial literacy, access to official money transfer systems, the ability to open Bank accounts, as well as to own and manage financial assets, investments and enterprises. Migrant workers are the first to respond during emergencies, natural disasters, political instability and economic turmoil by sending money home.

\section{Conclusion}

The population migration is an objective global socio-economic process. The main reason of the population migration is the unequal distribution of resources in the global world (Kozyr, 2018). The incentives and motives for the labour migration are people's 
perceptions of the life standard and work in different regions of the world. The desire to send money home for their relatives and friends is a normal human feeling.

To get financial flows from compatriots, governments are expanding the network of national banks abroad, offering favorable conditions for money transfers and deposits in foreign currency. At the same time, there are regions in the world where the cost of sending reaches $20 \%$. The high cost of remittances remains a serious barrier to reducing informal cash flows and to keeping earned cash at the disposal of migrant workers. The digitalization and breakthrough techniques are transforming the financial services market, which will contribute to reduce the cost of remittances to below $3 \%$ by 2030 .

Migrant remittances are more stable in comparison wiyh other funds, as they are less dependent on the world market. In our opinion, the information on the volume and the geography of cash flows shows the picture of the global labour migration. The volume of remittances will continue to grow (Sultanova and Chechina, 2016).

Cash transfers of migrant workers have a huge potential for the use in the economy of the host country. Their role is especcially significant for low-and middle-income countries. Families receiving remittances increase their purchasing power, reduce poverty, improve children's education, increase access to health care, and increase savings and investment. Thus, migrants' money transfers become an independent and very significant factor in the development of recipient countries.

\section{References:}

Cristea, M., Thalassinos, I.E. 2016. Private Pension Plans: An Important Component of the Financial Market. International Journal of Economics and Business Administration, 4(1), 110-115.

Global Forum on Remittances, Investment and Development 2018. Asia-Pacific Official report. IFAD. 2019. Available at:

https://www.ifad.org/documents/38714170/41038007/gfrid2018_report.pdf/a600fe3 e-ed69-091f-673d-6cd21a9fa305

IFAD. 2019. Available at: https://www.ifad.org/en/web/latest/story/asset/40323331

Kozyr, N.S., Petrovskaya, N.E., Zazimko, V.L. 2018. Modern Approaches Assessing Global Competitiveness. European Research Studies Journal, S2(21), 1034-1041.

Migration and Remittances Factbook 2016. World Bank Group. Available at: https://siteresources.worldbank.org/INTPROSPECTS/Resources/3349341199807908806/4549025-1450455807487/Factbookpart1.pdf.

Outward Remittance Flows. 2019. Available at: https://www.worldbank.org/.

Petrovskaya, N.E. 2019. Immigration to US from Sub-Saharan African Countries at the Second Decade of XXI Century. Asia and Africa today, 4, 41-46, doi: 10.31857/S032150750004382-2.

RemitScope. 2019. Available at: https://www.remittancesgateway.org/remitscope/.

Remittance Inflow. 2019. Available at: https://www.worldbank.org/.

Remittance prices worldwide. 2019. Available at: https://remittanceprices.worldbank.org/. 
Remittance Prices Worldwide. 2019. The World Bank, 30, June, available at: https://remittanceprices.worldbank.org/sites/default/files/rpw report_june 2019.pdf.

Rupeika-Apoga, R., Romanova, I., Bule, L., Thalassinos, E.Y. 2019. The Impact of Population Ageing and Social Stratification: The Case of Latvia. International Journal of Economics and Business Administration, 7(1), 49-63.

Sultanova, A.V., Chechina, O.S. 2016. Human capital as a key factor of economic growth in crisis. European Research Studies Journal, 19(S2), 71-78.

UN General Assembly. 2018. Intergovernmental Conference to Adopt the Global Compact for Safe, Orderly and Regular Migration Marrakech, Morocco, 2018. Available at: https://undocs.org/en/A/CONF.231/3.

UN IDF. 2019. UN International Day of Family Remittances. Available at: https://www.un.org/en/events/family-remittances-day/. 